\title{
11. ADDITIONAL PETROGRAPHIC STUDIES OF BASALTS, DSDP, LEG 38
}

\author{
M. Mohr, Bundesanstalt fur Geowissenschaften und Rohstoffe, D-3000 Hannover 51, Postfach 510153
}

\section{INTRODUCTION}

The petrographic results of Kharin (this volume) are essentially the same as those found by the author. However, an additional report seems necessary because most of the rock samples investigated by Kharin and by the author are not identical. Therefore, we present some additional descriptions for Sites 336, 344, and 348. There is, in one case, a small deviatory judgment concerning the petrography.

\section{BASALT PETROGRAPHY}

\section{Site 336, Core $\mathbf{4 4 - 1}$, to $\mathbf{4 4 - 2}$}

The replacement of olivine (and perhaps also pyroxene) by hydrobiotite as suggested by Kharin is not probable. There is a replacement of olivine by "iddingsites" as described by Wilshire (1958) and Baker and Haggerty (1967). According to these authors, olivine alters in two steps: (1) replacement of olivine by smectite-chlorite aggregates, and (2) a postdeuteric replacement of these aggregates by strongly pleochroitic (yellow-yellow-brown-reddish-brown) goethite-phyllosilicate aggregates called "iddingstites." This formation of "iddingsites" is also coupled with a metasomatic process (depletion of magnesium and enrichment of iron) as well with an oxidation of ferrous to ferric iron. An increasing pleochroism and birefringence depends on a layering of ordered goethite. According to Baker and Haggerty (1967), the formation of hydrobiotite out of "iddingsite" by a supply of potassium is possible only by hydrothermal reheating, or deep burial metamorphism. However, there is no evidence for this process in this basalt. In the case of metamorphism producing hydrobiotite, there should be additional characteristic mineral assemblages present (such as zeolite, prehnite, prehnite-pumpellyite-facies), and especially illite instead of smectite. A X-ray study yields, apart from the absence of hydrobiotite, no hint for the presence of illite.

\section{Site 344}

In Sample 36-3, 135-137 cm, there is a strong depletion of pyroxene and an enrichment of felsic components especially quartz and alkali feldspar. The latter is present in small amounts in nearly all samples from this hole, forming either irregular large rims at the plagioclase laths, or single crystals in the interstices. Furthermore, alkali feldspar and quartz form, in Sample $36-3,135-137 \mathrm{~cm}$, a xenomorphic granular texture, and a micrographic intergrowth, respectively (Figure 1). Quartz forms xenomorphic crystals up to $1 \mathrm{~mm}$, mostly skeletal developed. Smaller crystals are often hypidiomorphic or idiomorphic. These patches of

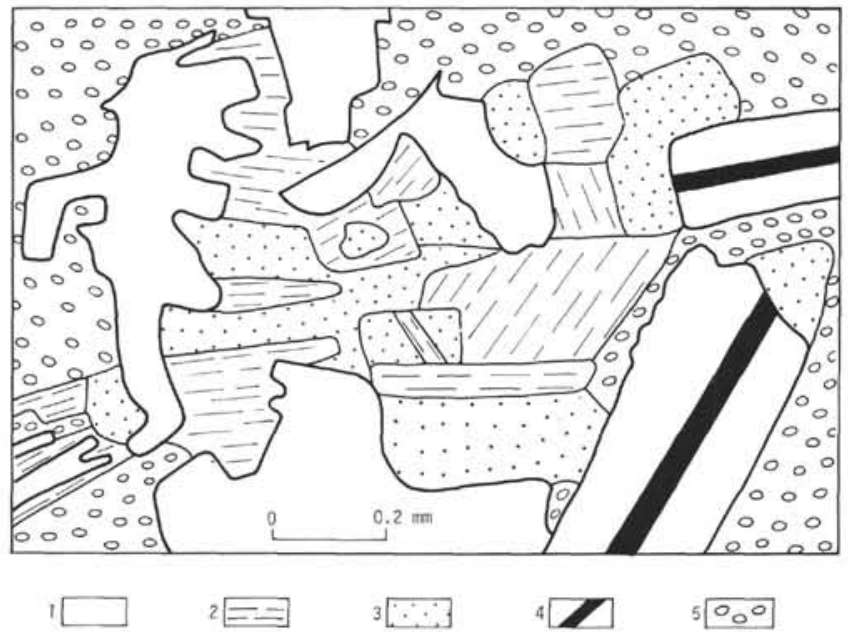

Figure 1. Intrusive doleritic basalt from Site 344. Quartzalkali feldspar intergrowth in Sample 36-3, 135-137 cm. (1) Quartz, single xenomorphic crystal; (2) alkali feldspar (3) micrographic intergrowth of quartz and alkali (4) plagioclase (5) smectite.

quartz and alkali feldspar intergrowths have an irregular distribution in thin section.

The chemical analysis of this sample shows well the enrichment of quartz and alkali feldspar and the depletion of pyroxene (especially the increase of $\mathrm{SiO}_{2}, \mathrm{Na}_{2} \mathrm{O}$, and $\mathrm{K}_{2} \mathrm{O}$, and the decrease of $\mathrm{MgO}$ and $\mathrm{CaO}$ ). Table 1 presents comparative information. The first column shows the general range of these oxides in the basalt from Site 344 except Sample 36-3, 135-137 cm, while the second column shows the values for this sample (36$3,135-137 \mathrm{~cm}$ ).

The differentiation index (Thornton and Tuttle, 1960) shows for Sample 36-3, 135-137 cm, the extreme high value of 57 , while the values of the other samples, are roughly between $25-35$. In this sample, there is obviously an in situ differentiation, either in the form of a

TABLE 1

Major Element Chemistry of Doleritic Basalt from Site 344

\begin{tabular}{lcc}
\hline & $\begin{array}{c}\text { Range of } \\
\text { Normal } \\
\text { Doleritic Basalt } \\
\text { Samples (wt \%) }\end{array}$ & $\begin{array}{c}\text { Differentiated } \\
\text { Basalt Sample } \\
\text { (wt \%) }\end{array}$ \\
\hline $\mathrm{SiO}_{2}$ & $46.04-50.57$ & 55.15 \\
$\mathrm{MgO}$ & $6.02-8.27$ & 3.31 \\
$\mathrm{CaO}$ & $9.88-12.14$ & 4.91 \\
$\mathrm{Na}_{2} \mathrm{O}$ & $2.79-3.24$ & 4.59 \\
$\mathrm{~K}_{2} \mathrm{O}$ & $0.32-0.98$ & 1.21 \\
\hline
\end{tabular}



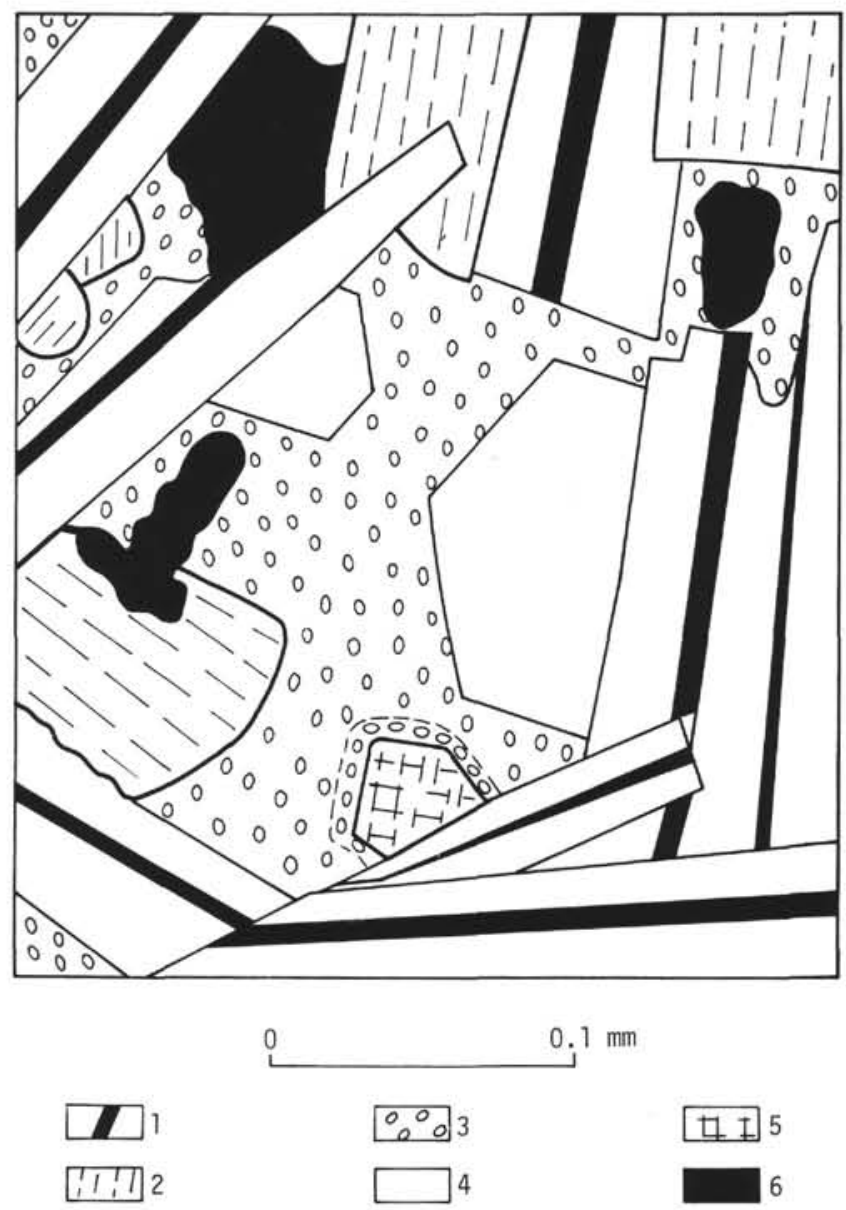

Figure 2. Medium-grained subophitic basalt from Site 348. Sample 33-7, $56-59 \mathrm{~cm}$. Interstice between plagioclase (1) and augite (2) filled with smectite (3) quartz (4), and pigeonite (5). The latter has an alteration rim of smectite. (6) ore.

layered horizon or as schlieren. The latter seems more probable, because in the thin section there are transitions between normal ophitic dolerite and parts with the enrichment of quartz and alkali feldspar.

\section{Site 348}

In Sample 33-7, 56-59 cm, grains of hypidiomorphic quartz $(0.1 \mathrm{~mm})$ appear rarely in the interstices of plagioclase and augite. Additionally, there are in the interstices, small crystals of pigeonite in subordinated amounts, aside from small augites. Figure 2 illustrates these characteristics, typical for tholeitic basalts.

\section{REFERENCES}

Baker, I. and Haggerty, S.E., 1967. The alteration of olivine in basaltic and associated lavas, Part II: Intermediate and low temperature alteration: Contrib. Mineral. Petrol., v. 16, p. $258-273$.

Thornton, C.P. and Tuttle, O.F., 1960. Chemistry of igneous rocks, I. Differentiation index: Am. J. Sci., v. 258, p. 664684.

Wilshire, H.G., 1958. Alteration of olivine and orthopyroxene in basic lavas and shallow intrusions: Am. Mineral., v. 43 , p. $120-147$. 